高い近似を示した。

\section{$328 \mathrm{CR}$ 用いた定位放射線治療位置精度検証の試み} 神戸大学医学部附属病院·放射線部 南 利明，岡山貴宣，川口忠孝 川瀬修三，神澤良明

【目的】定位放射線治療において，その位置付け精度の検証は非常に 重要である，その方法もさまざまで，CT-リニアックシステム，X 線-I.I.システムやTVカメラを用いた方法が挙げられる。しかしなが ら，これらのシステムは非常に高価であり，また導入するうえでそ のスペースの確保が必要になる，今回我々は，CR(KODAK社製)を 用いた定位放射線治療の位置精度検証を試み，有用な結果が得られ たので報告する。

【方法】CRを用いることにより，その画質㧍よび拡大率の再現性の確 保が重要となる，そこで1. 良好な画質を確保するため，照射線量 および照射野の関係から，得られた画像のSNRがどう変化するのか を検討した. 2. 拡大率の確保として, 既設のEPID (electorical portal imaging device) システムの駆動部を用い, 得られたCR画像の拡大率 の再現性を検討した. 3. 得られた画像から照射位置精度の確認が可 能かどうかの検討を行った.

【結果】EPIDの駆動部を用いCRの撮影を行うことで, 直線加速装置 のX線を用い，かつ良好な画質および拡大率の再現性が確保された 画像が得られた。このことにより本法は定位放射線治療における照 射位置の精度検証のためのシステムとして，その有用性が示唆され た.

329 ガンマナイフタイプCにおける不整形病変に対する照射の検 証

名古屋共立病院 - 放射線外科センター 林 直樹，森 美雅，小林達也 岐皁医療技術短期大学・診療放射線技術学科 内山幸男

名古屋共立病院·画像技術課 山田雅己，山室 修，滝川幸則 池之上宙

【目的】APS (Automatic Positioning System)を装備したガンマナイフタ イプCの登場により, 小口径コリメータによるマルチショットが簡 便にできるようになったため, 不整形の腫瘍やOAR (Organ at Risk) に近い病変でも腫湯に対し高線量かつConformityの高い線量計画を 立てることが可能となった。しかし，APSを利用した照射の線量評 価の報告はいまだ少ない，今回われわれはマルチショットによる照 射での線量分布の検討およびフィルム法による検証を行った。

【方法】直径 $16 \mathrm{~cm}$ の球形ファントムをレクセルGフレームに固定し, 治療計画用CTを撮影した. 球形ファントムの中心に不整形の病変を 設定し，14mmコリメータのみによる照射と $8 \mathrm{~mm}$ コリメータのみに よる照射の 2 通りの治療計画を行った。球形ファントムの中心に GAFchromicFilmを固定し, 照射を行った後, フィルム解析システム により解析を行った.

【結果】小口径コリメータによる照射は, 不整形の病変に対して良好 な線量分布を得ることができた。 また, 治療計画上の線量分布と フィルムから得た線量分布の比較では概ね一致していたが, 治療計 画上で辺縁が鋭角となるような部分ではフィルム法から得た分布と 若干の誤差が生じた.

【考察】APSを用いての小口径コリメータによる照射は精度も高く, 聴神経腫瘍や下垂体腺腫など近傍にOARの存在する病変で有用であ ると考える。しかし，辺縁が鋭角となるような部分では $50 \%$ 線量曲 線のみならず多数表示するなど注意が必要で，また小口径コリメー タのみの照射では照射時間も長くなることからコリメータの選択は 適切に行う必要があると考えられた。
330 定位放射線照射対応実験用固定枠の検討

東京女子医科大学病院・神経放射線科 臼倉政雄，吉田滋俊 森山紹敏, 梁川勝模

【目的】ガンマナイフを用いて小動物に照射を行う場合，固定及び照 射計画用撮影を精度良く行うことは繁雑であった，新しく開発され た，ガンマナイフModel C-APS System対応実験用固定枠RegisValliccioni frame (RVフレーム)が当院に導入され, 小動物を簡便に固 定でき，定位放射線照射を行える．今回，RVフレーム使用時の，照 射計画撮影，位置精度を検討したので報告する.

【方法】RVフレームに, 自作ファントムを固定し, 照射計画用CT, MRの比較撮影を行った。得られた画像の歪み，位置精度の測定， さらに, RVフレームをAPSに装着後, 専用QAツールで照射位置の 検討をした。また，ラット(重さ約 $340 \mathrm{~g}$ )に使用し，同様の検討を 行った.

【結果及び考察】ラットの脳に照射をする場合，CTでは解剖学的な位 置決定が難しく，MRが必要であり，撮影には3D-FISP法が適してい た. 頭部固定具の一部に, 金属アーチファクトが有った。しかし, ラットの脳に照射する場合，問題はなかった，位置精度は，左右方 向より頭尾方向の誤差が大きかった，RVフレームはラットを簡便に 固定し，頭部の目的部位に照射でき，有用性が確認できた。

331 高濃度X線フィルムのデイジタルデュープ作成に関する研究 岐阜大学産官学融合センター 篠原範充

岐皁大学大学院 ·医学系研究科再生医科学専攻再生工学講座知能イメー ジ情報分野 原 武史，藤田広志

国立病院機構名古屋医療センター・放射線科 遠藤登喜子

【目的】講習会や医事問題などにおいてデイジタル画像技術を利用し たディジタルデュープシステムが用いられている．胸部単純X線写 真においてはすでに実用化されているが，マンモグラムなどの高濃 度X線写真に対して使用した例はほとんどない。そこで，本研究で は，レーザースキャナとレーザーイメージャの特性を考慮した高濃 度X線写真のディジタルデュープシステムを提案する。

【方法】レーザースキャナ(Konica LD-5500)を用いてオリジナルフィ ルムをサンプリング間隔0.05mm，12bit階調でディジタル化し，その 画像をレーザーイメージャが出力することが可能な濃度域に変換す る。レーザーイメージャの最高濃度と線形性の管理には，画素值 145 4095を画素值50刻みで変化するデイジタルステップを用い た. 濃度変換には，乳房領域内の最高濃度と撮影法をもとに，乳房 領域内の光学濃度とコントラストを維持して変換する手法と乳房領 域のコントラストとスキンライン情報を維持して変換する手法の 2 つを併用した．本手法を7800枚のマンモグラムに適用し，ディジ夕 ルデュープフィルムを作成した。

【結果と考察】ディジタルデュープの評価は，習熟した医師によりマ ンモグラフィガイドラインを用いて視覚評価を行った，本手法によ り作成したディジタルデュープは，オリジナルフィルムと同等の診 断ができ，講習会などにおいて使用することが可能であると判断さ れた。しかし，濃度域によってはコントラストが圧縮されているた め十分に認識して使用する必要がある。さらに客観的評価により, 本手法の有効性を確認する必要がある。 